\title{
Physiological quality of Gossypium hirsutum L. seeds after the thermal delinting process
}

\author{
Pablo Radamés Cabral de França ${ }^{*}$, Francisco de Assis Cardoso Almeida², \\ Odilon Reny Ribeiro Ferreira da Silva ${ }^{3}$, Jeane Ferreira Jerônimo² \\ 'Pernambuco Institute of Education, Science and Technology, Vitória de Santo Antão, Brazil \\ ${ }^{2}$ Federal University of Campina Grande, Campina Grande, Brazil \\ ${ }^{3}$ Brazilian Agricultural Research Corporation, Campina Grande, Brazil \\ *Corresponding author, e-mail: pabloradames@hotmail.com
}

\begin{abstract}
The removal of lint from cotton seeds is mainly carried out through chemical delinting, but it is an expensive procedure and requires high technology. The objective was to evaluate the physiological quality of Gossypium hirsutum L. seeds delinted by flaming using a thermal delinter prototype. Cotton seeds BRS 286 were flamed in nine settings intensities and compared to chemical delinting and seeds with lint. We analyzed the water content, germination, first count, germination speed index (GSI), length and dry mass of roots and shoots. Using a completely randomized design and the means were compared by Scott-Knott test at $5 \%$ probability. In evaluating, the germination percentage did not differ between treatments with chemical and thermal low intensity delinting compared to the control. In vigor tests were observed higher mean values of the chemical treatment to the other treatments, except in GSI test and root dry weight when subjected to thermal delinting of low and medium intensity. The delinting made through the prototype enables efficient results, as well as the chemical delinting with sulfuric acid, without affecting germination and vigor when flamed with low and middle intensity, regardless of the number of active burners.
\end{abstract}

Keywords: flaming, cotton, germination, vigor

Introduction

The cotton crop (Gossypium hirsutum L.) is a species of great importance for the agricultural sector in the world, as highlights the works of Khalafalla \& Abdellatef (2008), Almeida et al. (2010), Silva et al. (2012), Naim et al. (2013), Marimuthu \& Subbian (2013) and Nazir et al. (2014) and, together with the species Gossypium barbadanse L., make up 98\% of world production according to Azmat \& Khan (2010).

In Brazil, G. hirsutum is the most produced species due to its characteristics, which can reach $38 \mathrm{~mm}$ in length, with low requirements to soil and climate, good resistance to drought and excellent fiber quality, especially in the semi-arid region (Richetti \& Melo Filho, 2001; Sousa et al., 2013). Along to these characteristics, there is a concern about the seeds quality used in the field, thus, when seeds have good quality they promote a vigorous seedling stand and an uniform crop, otherwise it will affect their development mainly influenced by environmental adversities (Bölek et al., 2013) and consequently in fiber quality. The physiological quality of the cotton seeds can be compromised in the processing, especially in the delinting, an unusual practice by the small producer of the Northeast region, forcing them to use the seed with linter for sowing, described by Lopes et al. (2006) and Sczostak (2009) as short fibers. These seeds may lead to the proliferation 
of fungi during storage, and according to Juliatti et al. (2011) this situation compromises the crop performance. The study of the beneficiation process has a fundamental importance due to the high seeds damage in consequence to error during the proper method choice. . This problem was verified by França et al. (2013) with castor bean seeds benefited by different methods, whose greater intensity of the process resulted in higher physical and physiological damages.

The de-sticking practice in cotton seeds is necessary mainly for mechanized sowing or when stored for a long period and can be carried out using chemical products whose seeds are primarily subjected to sulfuric acid. After the deslinting, the seeds are washed for the removal of the excess of chemical products, and can be treated with insecticides and stored, as observed by Ryavalad et al. (2009) with the neonicotinoid imidacloprid.

Another method is flaming that refers to the seed delinting by burning the linter, performed by the direct contact of the fire with the seed surface. The flaming of cotton seeds is currently in disuse, but has positive results when working with agroecological production.

The evaluation of seeds physiological quality consists in the realization of germination and vigor tests, that allow to determine the moment in which the embryonic axis continues its development and its capacity to promote a vigorous plant stand (Carvalho \& Nakagawa, 2012) in delinted cotton seeds has great importance, since they provide a vigorous stand of the seedlings, whose great difficulty to obtain success in the cotoniculture, according to Lauxen et al. (2010) is the acquisition of good quality seeds.

In spite of the studies on cotton seed delinting, the flaming method is poorly used nowadays. The aim of this study was to evaluate the physiological quality of $G$. hirsutum L. seeds by means of flaming using a thermal delinter prototype.

\section{Material and Methods} Local

The cotton seeds were from cultivar BRS 286, obtained in an experimental area of EMBRAPA in Mogeiro - PB, crop 2013. The experiment was carried out in two stages with different areas from July 2013 to February 2014, with the first stage carried out at Embrapa Algodão, located in Campina Grande, where $100 \mathrm{~kg}$ of seeds were ginned by a small power plant of 25 saws developed and described by Jerônimo et al. (2013) and then $50 \mathrm{~kg}$ of seeds were submitted to thermal delinting.

The second step consisted in the seeds chemical delinting of a five kilograms sample randomly collected from those that were ginned in the previous stage. Thus, the delinting was carried out in the Laboratory of Storage and Processing of Agricultural Products of the Federal University of Campina Grande, where germination tests were conducted, first count and the germination speed index, as well as length and dry mass of roots and aerial part of seedlings resulted from the seeds delinting in both processes.

\section{Delinting methods}

The delinting process was carried out using two different methods: thermal - consisted of the delinting by the linter burning adhered to the cotton seeds, performed by a prototype developed by the authors, and chemical consisted of the seeds immersion in commercial sulfuric acid at $98 \%$ in the proportion of one liter for each seven kilos of seeds based on the experiment of Queiroga et al. (2009).

For the thermal delinting test, three flame intensities were evaluated (low $=3,307.5 \mathrm{Kcal} / \mathrm{h}$, middle $=27,534.9 \mathrm{Kcal} / \mathrm{h}$, high $=53,664.2 \mathrm{Kcal} /$ h) were determined by the equation:

$$
Q=D \cdot P C l
$$

Where:

$Q=$ thermal power in relation to flow / fuel consumption (Kcal/h)

$D$ = fuel consumption by hour $(\mathrm{Kg} / \mathrm{h})$

$\mathrm{PCl}=$ calorific value of fuel $(\mathrm{Kcal} / \mathrm{kg})$

In addition to the intensities described above, three burner use configurations were tested, totaling nine treatments for thermal delinting. Also, the chemical delinting and the 
control (linted seeds) were tested, as can be seen in Table 1.

Water content

Table 1.Treatments to evaluate the physical and physiological quality of $G$. hirsutum seeds.

\begin{tabular}{cc}
\hline TREATMENTS & Tests \\
\hline T1 & Linted seed (control) \\
T2 & Chemical delinting \\
T3 & Thermal - low flame, 1 active burner \\
T4 & Thermal - low flame, 2 active burners \\
T5 & Thermal - low flame, 3 active burners \\
T6 & Thermal - middle flame, 1 active burner \\
T7 & Thermal - middle flame, 2 active burners \\
T8 & Thermal - middle flame, 3 active burners \\
T9 & Thermal - high flame, 1 active burner \\
T10 & Thermal - high flame, 2 active burners \\
T1 1 & Thermal - high flame, 3 active burners \\
\hline Low flame $=3,307.5 \mathrm{kcal} / \mathrm{h}$; Middle flame $=27.534 .9 \mathrm{kcal} / \mathrm{h}$; High flame $=53,664.2 \mathrm{kcal} / \mathrm{h}$
\end{tabular}

Before each delinting test the water content of the seeds was determined using four replicates with approximately $10 \mathrm{~g}$ of seeds for each treatment, with a mean of 80 seeds for each sample. They were placed in metal containers, weighed and placed in the incubator at $105 \pm 3$ ${ }^{\circ} \mathrm{C}$ for 24 hours. After this procedure, the recipients were capped and cooled in a desiccator for a period of 15 minutes and weighed in an analytical balance with an accuracy of $0.001 \mathrm{~g}$. The water content was calculated according to Brazil (2009) and expressed in percentage.

\section{Germination test}

This test was performed in four replicates of 50 seeds (Mattioni et al., 2012) placed on a towel paper substrate (germitest) that was distributed on two sheets, covered with a third and organized in the form of a roll. The substrate was moistened according to Brazil (2009), with distilled water in the volume $(\mathrm{mL})$ equivalent to 2,5 times the mass of the dry substrate, with no subsequent water addition. The rolls were packed in $0.04 \mathrm{~mm}$ thick plastic bags to prevent moisture loss and placed in Biochemical Oxigen Demand (B.O.D.) germinators-type at a constant temperature of $25{ }^{\circ} \mathrm{C}$. Germinated seedling percentage evaluations were performed daily, starting on the 4th day after the test installation for a period of 12 days; considering the germination of the seeds that emitted the primary root and the aerial part.

First germination count
The first count was performed on the fourth day after the beginning of the test (Brazil, 2009), conducted in parallel with the germination test, and the results were expressed in percentage.

\section{Germination Speed Index (GSI)}

The germination speed index was performed in conjunction with the germination test, using daily counts of normal seedlings from the 4th to the 12th day after sowing (Brazil, 2009). The index was calculated using the formula proposed by Maguire (1962).

\section{Seedlings length}

At the end of the experiment, 12 days, the aerial part and primary root of the seedlings were measured separately with a millimeter ruler, and the results were expressed in centimeters.

\section{Seedlings dry mass}

The normal seedlings were separated into roots and aerial part with scissors and then separately placed in paper bags, taken to a forced air circulation incubator set at $65^{\circ} \mathrm{C}$ for 48 hours. After this period the samples were weighed on analytical balance $(0.001 \mathrm{~g})$ and the results were expressed in g.seedling ${ }^{-1}$.

\section{Experimental design and statistical analysis}

The experimental design was completely randomized with four replicates of 50 seeds for each test. The obtained data were submitted to the analysis of variance using the $F$ test for 
comparison of the mean squares and the means compared by the Scott Knott test at $5 \%$ of probability. For statistical analysis the ASSISTAT software version 7.7 beta - 2014 was used.

\section{Results and Discussion}

After the delinting process, it was possible to observe, according to the results contained in Table 2, the highest mean values of water content for the treatment related to the chemical delinting (T2), differing significantly from the other treatments. Thus, the high percentage value is evident due to the chemical delinting procedure adopted. Those whose seeds were submitted to flames with a calorific value of $53,664.2 \mathrm{Kcal} / \mathrm{h}$ (T9, T10 and T1 1) presented values below $8.40 \%$.

According to Mota et al. (2009) for the realization of the beneficiation was used the concentrated sulfuric acid and it acts as catalyst of the reaction of partial acid hydrolysis; this occurs when the acid comes in contact with the cotton fibers, which are made of cellulose. As for the waste generated by the delinting, there are many ways that are intended to depend on the technology used in the process. Most of the time, the residue, sulfuric acid and water, are not properly destined and are disposed directly on the soil without any treatment, corresponds to approximately $95 \%$ of the acid that is used in the delinting. Another form is through the neutralization with liquid ammonia (Gabriel et al., 2015), and thus it can be destined to the companies that reuse for the fertilizers production.

After the seeds submersion in the sulfuric acid they are washed in running water until the chemical residues are completely eliminated, which favors the absorption, raising the water content in cotton seeds. It is important to correlate the moisture present in the seed with the vigor test, since, according to Dutra \& Medeiros Filho (2008), it can affect its behavior interfering in the physiological capacity. The assertion of these authors corroborates with the observed in this study, when the seeds were submitted to T2, showed 8.74 percentage points more than the other treatments and when correlated with the vigor tests in Table 2 and 3, we observed that the values stood out to the others.

In the treatments with thermal delinting, with high flame intensity, the water contents were inferior to $8.70 \%$, did not obtain statistical difference between them, as well as the control, with a lower percentage value $(7.97 \%)$ for treatment with higher incidence of flame in the seeds (T11). A similar result was obtained by Queiroga et al. (1993), in which there were no significant differences in water content between the treatments with different flame intensities in the seed delinting.

In the treatments with low water content described above, they were possibly affected by the high internal temperature of the flame chamber, reaching values above $40^{\circ} \mathrm{C}$, with a maximum of $54.6^{\circ} \mathrm{C}$ in 20 minutes of testing. It is worth noticing that in the prototype used the time of exposure of the seeds to the heat is fast (1.17 $\left.\mathrm{m} . \mathrm{s}^{-1}\right)$; otherwise, a period of high temperatures

Table 2. Mean values of water content, germination test and first count in $\mathrm{G}$. hirsutum seeds submitted to delinting treatments.

\begin{tabular}{cccc}
\hline TREATMENTS & Water content (\%) & Germination (\%) & First Count (\%) \\
\hline T1 & $8.53 \mathrm{~b}$ & $96 \mathrm{a}$ & $91 \mathrm{~b}$ \\
T2 & $17.75 \mathrm{a}$ & $97 \mathrm{a}$ & $96 \mathrm{a}$ \\
T3 & $8.80 \mathrm{~b}$ & $96 \mathrm{a}$ & $88 \mathrm{~b}$ \\
T4 & $8.78 \mathrm{~b}$ & $96 \mathrm{a}$ & $89 \mathrm{~b}$ \\
T5 & $8.81 \mathrm{~b}$ & $96 \mathrm{a}$ & $90 \mathrm{~b}$ \\
T6 & $9.01 \mathrm{~b}$ & $94 \mathrm{~b}$ & $90 \mathrm{~b}$ \\
T7 & $8.68 \mathrm{~b}$ & $94 \mathrm{~b}$ & $90 \mathrm{~b}$ \\
T8 & $8.55 \mathrm{~b}$ & $93 \mathrm{~b}$ & $90 \mathrm{~b}$ \\
T9 & $8.33 \mathrm{c}$ & $93 \mathrm{~b}$ & $90 \mathrm{~b}$ \\
T10 & $8.16 \mathrm{c}$ & $92 \mathrm{~b}$ & $90 \mathrm{~b}$ \\
T1 & $7.97 \mathrm{c}$ & $92 \mathrm{~b}$ & $91 \mathrm{~b}$ \\
\hline CV (\%) & 2.84 & 1.48 & 2.07 \\
\hline Mean Point & 12.98 & 94 & 92 \\
\hline
\end{tabular}

$\mathrm{T} 1=$ without delinting; $T 2=$ chemical delinting; $T 3=$ low flame $/ 1$ burner; $T 4=$ low flame $/ 2$ burners; $T 5=$ low flame $/ 3$ burners; $T 6=$ middle flame $/ 1$ burner; $T 7=$ middle flame $/ 2$ burners; $T 8=$ middle flame $/ 3$ burners; $T 9=$ high flame $/ 1$ burner; $T 10=$ high flame $/ 2$ burners; $T 11=$ high flame $/ 3$ burners. Means followed by the same letter in the column did not differ by Scott-Knott test with $5 \%$ of probability. 
would reduce germination of the seeds, and could change physicochemical characteristics, since one of the conditions of susceptibility of the seeds to the mechanical damages is in function of the water content. According to the affirmation of Sutar et al. (2013), which complements that the study of water content related to its physical properties, are important because they provide the basis for the preparation of equipment and the elaboration of procedures used in the processing.

In the evaluation of the germination percentage (Table 2), there was no significant difference between the treatments with chemical delinting (T2) and low thermal intensity (T3, T4 and $\mathrm{T} 5$ ) in relation to the control (T1), although with a small advantage in the treatment with sulfuric acid (97\%), and these differed from the other treatments. A similar result was observed in the experiment carried out by Maeda et al. (1977), whose chemical delinting (94\%) showed a higher value than thermal (77\%), but with a large difference. The lowest mean value was observed when the seeds were submitted to the $\mathrm{T} 11$ treatment, with $92 \%$, a result obtained probably due the high flame intensity to which the seeds were submitted, causing a reduction in the germination power of the seeds.

These results are correlated to the efficiency of the method used, with the main factor of the chemical treatment being the total loss of linter in the seed, while in the thermal delinting the loss was partial (Carvalho \& Nakagawa, 2012). This difference in the amount of linter before and after the thermal delinting is demonstrated in the Figure 1.

The linter adhered to the seeds may make it difficult to water absorption and, consequently, promote the germination delay, a characteristic structure in species of arid and semi-arid regions and very important for its survival. However, even if characterized as a survival mechanism it can stop the water absorption, being essential for the germination process. According to Carvalho \& Nakagawa (2012), water is responsible for the hydration initiation of the seed tissues, and, consequently, for the intensification of respiration and all the metabolic processes necessaries for digestion and mobilization of reserves, resulting in the resumption of embryonic axis growth and seedling formation. It is noted that the flame intensities as the number of active burners does not significantly interfere in the germination of cotton seed. These results corroborate with those obtained in the experiments of Cauquil \& Bonnet (1968), Toledo \& Barbin (1968) and Santiago (1978), in which there was no detection of damage to cotton seed germination with flame.

The thermal delinting evaluated by Bezerra et al. (1990) provided good results, which, working with the cultivar CNPA Acala 1, verified that in the flambed seeds there was a mean germination percentage of $78 \%$ (only one flame passage). They also observed that according to the number of times the seed passages through the flame the result is differentiated, obtaining a germinative percentage of $79 \%$ when the seeds were submitted twice and $30 \%$ when they were submitted three times to the flame. It was also verified satisfactory results for the flaming method by Queiroga et al. (1993), because it promoted a significant increase in the germination and vigor of the cotton seeds and that the weight loss of the seed was proportional to the number of the seeds passages by the equipment tube.

According to the percentage values

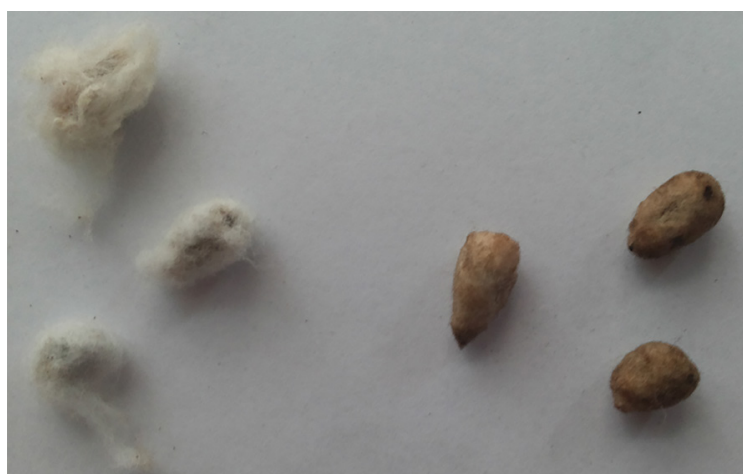

Figure 1. Comparison between seeds of $\mathrm{G}$. hirsutum before (left) and after (right) the thermal delinting at high intensity with the three active burners. 
of the first count (Table 2), it was verified that there was no statistical difference between the treatments submitted to the thermal delinting as well as the control. A maximum value was obtained for the seeds from the chemical delinting (96\%), which differed from the other treatments and lower value (88\%) for the seeds submitted to T3 treatment. These results are in agreement with the data obtained by Queiroga et al. (2009), who concluded that delinted cotton seeds (without linter) had higher first count values than flambed seeds and seeds with linter.

Seeds that showed a higher percentage of first count will give rise to more vigorous seedlings, that is, those that germinate faster, will promote the formation of more normal seedlings (Brazil, 2009). Thus, the delinting studied here allow to produce vigorous seedlings.

Among the seeds submitted to thermal delinting, the treatment in which the middle flame intensity was tested and with only one working burner allowed a higher percentage value in the first count, a result that was again observed. Both the germination percentage and the first count values were highlights for this treatment, although there was no statistical difference between the others, leading them to verify that the method of flaming promoted by the prototype under study, promoted a greater germinative process in this relation of flame intensity and number of active burners, necessary for a delinting in which one seeks to obtain greater germinative power.

In Table 3, the values of germination speed index, length and dry mass of roots and shoots of cotton seedlings are presented. Seedlings submitted to chemical delinting provide higher seedlings for the germination speed index, however, for the seeds submitted to the two methods of delinting there were no significant differences, allowing to affirm that in order to obtain vigorous seedlings, the delinting with sulfuric acid and flaming in the prototype are equally efficient.

Regarding rootand shootlength (Table 3),

Table 3. Germination speed index (GSI), length and dry mass of root and shoot in G. hirsutum seeds, submitted to delinting treatments.

\begin{tabular}{|c|c|c|c|c|c|}
\hline \multirow{2}{*}{ TREATMENTS } & \multirow{2}{*}{ GSI } & \multicolumn{2}{|c|}{ Length $(\mathrm{cm})$} & \multicolumn{2}{|c|}{ Dry mass (g/seedling) } \\
\hline & & root & aerial part & root & aerial part \\
\hline $\mathrm{Tl}$ & $8.79 \mathrm{a}$ & $4.55 \mathrm{C}$ & $6.08 d$ & $0.140 d$ & $0.545 \mathrm{~d}$ \\
\hline $\mathrm{T} 2$ & $10.61 \mathrm{a}$ & $14.47 \mathrm{a}$ & $13.31 \mathrm{a}$ & $0.270 a$ & $1.528 \mathrm{a}$ \\
\hline T3 & $9.33 \mathrm{a}$ & $4.38 \mathrm{c}$ & $6.40 \mathrm{~d}$ & $0.202 a$ & $0.906 \mathrm{c}$ \\
\hline T4 & $9.32 \mathrm{a}$ & $3.97 c$ & $6.22 \mathrm{~d}$ & $0.226 a$ & $1.056 b$ \\
\hline T5 & $9.47 \mathrm{a}$ & $4.49 \mathrm{C}$ & $6.82 \mathrm{~d}$ & $0.250 a$ & $1.262 \mathrm{~b}$ \\
\hline T6 & $10.00 \mathrm{a}$ & $8.87 \mathrm{~b}$ & $9.94 \mathrm{~b}$ & $0.206 a$ & $0.991 b$ \\
\hline $\mathrm{T} 7$ & $9.24 \mathrm{a}$ & $8.33 \mathrm{~b}$ & $9.05 \mathrm{~b}$ & $0.211 a$ & $0.840 \mathrm{c}$ \\
\hline T8 & $9.74 \mathrm{a}$ & $8.55 b$ & $8.17 \mathrm{c}$ & $0.216 a$ & $0.772 \mathrm{c}$ \\
\hline T9 & $9.45 a$ & $9.34 \mathrm{~b}$ & 9.68 b & $0.174 b$ & $1.131 \mathrm{~b}$ \\
\hline $\mathrm{T} 10$ & $9.46 \mathrm{a}$ & $8.69 \mathrm{~b}$ & $10.12 \mathrm{~b}$ & $0.181 \mathrm{~b}$ & $1.133 \mathrm{~b}$ \\
\hline $\mathrm{T} 11$ & $9.59 \mathrm{a}$ & $8.39 \mathrm{~b}$ & $10.93 \mathrm{~b}$ & $0.186 b$ & $1.130 \mathrm{~b}$ \\
\hline CV (\%) & 7.58 & 8.13 & 9.05 & 18.96 & 11.91 \\
\hline Middle point & 9.52 & 9.88 & 11.10 & 0.226 & 1.029 \\
\hline
\end{tabular}

a statistical superiority was obtained for seedlings from chemically delinted seeds, resulting in 14.47 and $13.31 \mathrm{~cm}$, respectively, whose root length value was higher than that presented by Farias et al. (2003), who studied the effect of seedling growth with and without linter, obtained seeds with a mean value of $12.59 \mathrm{~cm}$, also delinted by sulfuric acid. Although, when comparing the mean value of seed root length with linter (12.23 $\mathrm{cm})$, there was a large difference of the value obtained in this work $(4.55 \mathrm{~cm})$.

The mean rootlength of the seedlings from the treatments with the seeds' thermal delinting showed that, when submitted to the flame of low intensity, T3, T4 and T5 presented lower values than the other treatments, with respectively 4.38 , 3.97 and $4.49 \mathrm{~cm}$. When submitted to the middle and high flame intensities, the seeds gave rise 
to more vigorous seedlings, practically twice as large as the seeds from the low flame test. These results contradict those observed by Queiroga et al. (1993), because they verified that the use of flaming with mild fire (low) in the cotton seed in the thermal delinting, significantly increased the vigor of itself, while the delinting with fire of greater intensity decreased significantly the vigor as well as the germination when compared to control values (linter seeds).

Seeds when flambed at low intensity did not promote a satisfactory development of the root, which was probably caused by delayed germination, that is, when delinted with intensities of 27,534.9 and 53,664.2 Kcal / h (middle and high), besides reducing the amount of linter adhered to the seed surface, allowed an increase in cell permeability membranes due to the formation of surface fissures.

As regards the length of the aerial part (Table 3), previously reported, the chemical delinting stood out among the other treatments $(13.31 \mathrm{~cm})$. Among the thermal stresses, a similar effect was observed to the results obtained in the root length, whose values of the seeds submitted to middle and high intensities of the flame stand out to those of low intensity, differing significantly among themselves and presenting values below $7 \mathrm{~cm}$. However, except for the 18 treatment in which the seedlings come from seeds submitted to the middle flame with two active burners, which differ statistically from the low intensity treatments.

The results obtained in the evaluation of the length of the aerial part resemble the evaluation of the root, being thus, the fact that the seeds submitted to the low temperatures present smaller values corroborate with the same justification, whose middle and high intensities allowed a greater permeability of the cellular membrane, facilitating the development of the root and consequently of the aerial part.

The results of the root and shoot dry mass test (Table 3) confirm a slight advantage of the use of sulfuric acid in the cottonseed delinting, differing statistically from the high intensity thermal delinting (treatments T9, T10 and $\mathrm{T11}$ ), with mean values of 0.270 and 1.528 g.seedling ${ }^{-1}$ and shoot dry mass, respectively. A discrepancy between the treatments $\mathrm{T} 2$ and $\mathrm{T} 1$ was also found in both evaluations, with values of 0.140 and $0.545 \mathrm{~g}$. seedling ${ }^{-1}$ and shoot dry mass for $\mathrm{Tl}$. This superiority was also observed by Jerônimo et al. (2006) between chemically delintig seeds and linter seeds in two cultivars, BRS $1878 \mathrm{H}$ and BRS 200 Marrom. Although it has advantages in vigor, chemical delinting is not feasible for agroecological and organic production, because this kind of production does not allow the use of chemicals in any process of the primary chain, as well as, in the conventional, which requires reduced costs at any link of the cultivation system.

In addition to the restriction of chemical delinting for the processing of agroecological cotton, this type of cultivation is carried out predominantly by family farmers, which makes it unfeasible to handle the acid for the procedure due to the inadequate property structure and inexperience of the operator. In addition, for its commercialization, there must be the permission of the Federal Police or the Army, making the acquisition of the same more complex. Furthermore, the producer will suffer damages regarding the environmental impacts if there is no regular disposal of the residue (solution of sulfuric acid and water), because at the end of the delinting, about $95 \%$ of the acid residue used at the start of the process is obtained.

In general, the flame with middle intensity and one active burner (T6) presented, among the flaming treatments, results that put it as an alternative for the delinting of the agroecological cotton. In addition, thermal delinting is an applicable method for agroecological cotton crops because it does not produce chemical residues and the levels of carbon dioxide are negligible when compared to the environmental damage caused by sulfuric acid. Besides that, according to the results of the flaming process by the prototype, it is a method that does not present significant difference when compared to the chemical delinting, allowing to use it as an alternative to the agroecological production of cotton, fundamental to propitiate the resumption of this culture in the Northeast of Brazil. Almeida et al. (2011) report that the cultivation was limited by the lack of machines 
that aided in cotton processing and that were economically accessible to the small producer, since they promote quality to the final product. This statement is consistent with Silva et al. (2010), whose machines used in the processing, mainly the pre-cleaning, result in a better commercialization of itself.

It is worth noting that before the delintig process there is a necessity for ginning, and according to Koç \& Demiryürek (2005), Holt \& Laird $(2008 ; 2010)$ when not properly carried out, it can cause a negative effect on the physiological quality of cotton seeds, could mask the results of the delinting treatments. Considering the results obtained in this work it is observed that the ginning stage had no influence, because as the seeds were processed equally and with strict care in the adjustment of the machine, differences were observed only when delinted.

\section{Conclusions}

Among the thermal treatments, the flame with middle flame and one active burner (T6) presented, in general, results that put it as an alternative for the delinting of agroecological cotton.

The flaming delinting in the developed prototype results in seeds with physical and physiological quality similar to those delinted by the chemical method.

The germination percentage of the seeds submitted to the thermal delinting, regardless of the flame intensity, reached a minimum of $92 \%$.

\section{Acknowledgment}

We thank the Coordination of Improvement of Higher Education Personnel (CAPES) and the Postgraduate Program in Agronomy of the CCA / UFPB for enabling the development of the research.

We thank Embrapa Algodão and the Laboratory of Storage and Processing of Agricultural Products of the UFCG for providing resources and infrastructure to carry out the activities.

\section{References}

Almeida, F.A.C., Araújo, M.E.R., Silva, O.R.R.F., Santos, J.F., Gomes, J.P. 2011 . Desenvolvimento e avaliação de descaroçador para o beneficiamento do algodão. Revista Brasileira de Engenharia Agrícola e Ambiental 15: 607-614.

Almeida, F.A.C., Jerônimo, E.S., Alves, N.M.C., Gomes, J.P., Silva, A.S. 2010. Estudo de técnicas para o armazenamento de cinco oleaginosas em condições ambientais e criogênicas. Revista Brasileira de Produtos Agroindustriais 12:189-202.

Azmat, M.A., Khan, A.A. 2010. Assessment of genetic diversity among the varieties of Gossypium arboreum and Gossypium hirsutum through random amplification of polymorphic DNA (RAPD) and simple sequence repeat (SSR) markers. Pakistan Journal of Botany 42: 3173-3181.

Bezerra, J.E.S., Pereira, J.P.G., Firmino, P.T., Cabrae, R.R. 1990. Desenvolvimento de um miniflambador para uso de médios produtores de sementes de algodão. In: Reunião Nacional do Algodão, 6. Campina Grande. Anais... Campina Grande, EMBRAPA/CNPA, 150 p.

Bölek, Y., Nas, M.N., Çokkizgin, H. 2013. Hydropriming and hot water-induced heat shock increase cotton seed germination and seedling emergence at low temperature. Turkish Journal of Agriculture and Forestry 37: 300-306.

Brasil, Ministério da Agricultura, Pecuária e Abastecimento. 2009. Regras para análise de sementes. MAPA/ACS, Brasília, Brazil. 395 p.

Carvalho, N.M., Nakagawa, J. 2012. Sementes: ciência, tecnologia e produção. Funep, Jaboticabal, Brazil. 590 p.

Cauquil, J., Bonnet, G. 1968. Le flambage dês graines de semences du cotonnier. Coton et Fibres Tropicales 23: 503-505.

Dutra, A.S., Medeiros Filho, S. 2008. Teste de deterioração controlada na determinação do vigor em sementes de algodão. Revista Brasileira de Sementes 30:19-23.

Farias, V.A., Lima, C.L.D., Severino, L.S., Beltrão, N.E.M., Cardoso, G.D. 2003. Crescimento inicial de sementes de algodão com e sem línter sob diferentes lâminas de irrigação. In: Congresso Brasileiro de Algodão, 4., Goiânia. Anais... Goiânia, EMBRAPA-CNPA, CDROM.

França, P.R.C., Almeida, F.A.C., Silva, O.R.R.F., Jerônimo, J.F. 2013. Qualidade física e fisiológica de sementes de Ricinus communis L. após o processo de descascamento. Comunicata Scientiae 4: 153-160.

Gabriel, D., Trombetta, G., Henrique, G., Perecin Júnior, H., Muniz, R., Souza, L.C.D.2015. Deslintamento de sementes de algodão. Revista Conexão Eletrônica 12: 1-9

Holt, G.A., Laird, J.W. 2008. Initial fiber quality 
comparisons of the power roll gin stand to three different makes of conventional gin stands. American Society of Agricultural and Biological Engeineers 24: 295-299.

Holt, G.A., Laird, J.W. 2010. Power roll gin stand technology: Evaluation and optimization of rib rail angle and ginning point modifications on a retrofitted lummus gin stand. American Society of Agricultural and Biological Engineers 26: 209-215.

Jerônimo, J.F., Almeida, F.A.C., Silva, O.R.R.F., Queiroga, V.P., Santos, J.W. 2006. Propriedades física e fisiológica de sementes de algodão beneficiadas em três máquinas descaroçadoras. Revista Brasileira de Oleaginosas e Fibrosas 10: 1025-1031.

Koç, E, Demiryürek, O. 2005. Theoretical investigation of separator unitis in saw-gin machines. I: Cotton flow rate estimation. Fibres \& Textiles in Eastern Europe 13: 78-83.

Jerônimo, J.F., Silva, O.R.R.F., Almeida, F.A.C., Sofiatti, V., França, P.R.C., Brandão, Z.N. 2013. Desenvolvimento e avaliação de um descaroçador e prensa enfardadeira itinerantes para o beneficiamento do algodão. Revista Brasileira de Engenharia Agrícola e Ambiental 17: 319-326.

Juliatti, F.C., Bianco Junior, R.D., Martins, J.A.S. 2011. Qualidade fisiológica e sanitária de sementes de algodoeiro produzidas nas regiões do Triângulo Mineiro e sul de Goiás. Bioscience Journal 27: 24-31.

Khalafalla, M.M., Abdellatef, E. 2008. In vitro multiple shoot induction and plant regeneration in elite sudanese cotton (Gossypium hirsutum L.) cultivar (Barac-B-67). Journal of Innovation and Development Strategy 2: 77-82.

Lauxen, L.R., Villela F.A., Soares, R.C. 2010. Desempenho fisiológico de sementes de algodoeiro tratadas com tiametoxam. Revista Brasileira de Sementes 32: 061-068.

Lopes, K.P., Bruno, R.L.A., Costa, R.F., Bruno, G.B., Rocha, M.S. 2006. Efeito do beneficiamento na qualidade fisiológica e sanitária de sementes do algodoeiro herbáceo. Revista Brasileira de Engenharia Agrícola e Ambiental 10: 426-435.

Maeda, J.A., Lago, A.A., Zink, E., Krzyzanowski, F.C., Cia, E., Rodrigues Filho, F.S.O., Ferraz, C.A.M. 1977. Germinação de sementes de algodoeiro deslintadas por diferentes métodos. Bragantia 36: 253-258.

Maguire, J.D. 1962. Speed of germination-aid in selection and evaluation for seedlig emergence and vigor. Crop Science 2: 176-177.

Marimuthu, S., Subbian, P. 2013. Integrated nutrient management on weed dynamics of cotton based cropping systems in South India. SAARC Journal of Agriculture 1 1: 7-22.

Mattioni, F., Albuquerque,M.C.F., Marcos-Filho, J.,Guimarães, S.C. 2012. Vigor de sementes e desempenho agronômico de plantas de algodão. Revista Brasileira de Sementes 34: 108116.

MOTA, E. G., FINZER, J. R. D., RIBEIRO, E. J. 2009. Impacto ambiental da produção de sementes de algodão. In: Congresso Brasileiro de Algodão. Anais... Foz do Iguaçu, Brazil. CDROM.

Naim, A.M.E., Abdalrasol, O., Ahmed, M.F. 2013. Growth and yield of seed cotton response to plant spacing and weeding frequency under flood irrigation. Journal of Renewable Agriculture 1: 2732

Nazir, M.S., Saad, A., Anjum, Y., Ahmad, W. 2014. Possibility of seed priming for good germination of cotton seed under salinity stress. Journal of Biology, Agriculture and Healthcare 4: 66-69.

Queiroga, V.P., Bezerra, J.E.S., Correia, L.J. 1993. Deslintamento à flama da semente de algodão (Gossypium hirsutum L.). Revista Brasileira de Sementes 15: 7-12.

Queiroga, V.P., Castro, L.B.Q., Gomes, J.P., Silva, A.L., Alves, N.M.C., Araujo, D.R. 2009. Qualidade fisiológica de sementes de algodão armazenadas em função de diferentes tratamentos e cultivares. Revista Brasileira de Produtos Agroindustriais 11: 43-54.

Richetti, A., Melo Filho, G. A. 2001. Aspectos socioeconômicos do algodoeiro. Algodão: tecnologia de produção. Embrapa Agropecuária Oeste, Dourados, Brazil. p. 13-34.

Ryavalad, S., Patil, N.K.B., Giraddi, R.S., Katageri, I.S. 2009. Effect of acid delinting seed treatment and containers on storability of cotton hybrid. Karnataka Journal Agricultural Sciences 22: 5660.

Santiago, I.M. 1978. Influência do deslintamento à flama e químico sobre a germinação, o vigor e o desempenho no campo de sementes de algodoeiro (G. hirsutum L.).70f. (Dissertação de Mestrado) - Universidade de São Paulo, Piracicaba, Brazil.

Sczostak, A. 2009. Cotton linters: an alternative cellulosic raw material. Macromolecular Symposia 280: 45-53.

Silva, M.C., Toselli, M.E., Casenave, E.C. 2012. Poder germinativo en algodón, una metodologia al alcance del produtor. Cultivos Tropicales 33: 41-45. 
Silva, O.R.R.F., Sofiatti, V., Santana, J.C.F., Wanderley, M.J.R., Santos, J.W. 2010. Impacto do beneficiamento sobre o número de neps e quantidade de impurezas da fibra do algodão. Revista Brasileira de Engenharia Agrícola e Ambiental 14: 107-112.

Sousa, S. S., Lima, A. K. V. O., Beltrão, N. E. M., Silva, D. M. 2013. Algodão colorido: alternativa agroindustrial para o semiárido. In: Pereira, F. C., Furtado, D. A., Lima, A. K. V. O., Santana, M. F. S., Pereira, D. D., Veras, R. P. Recursos naturais do semiárido: oportunidades agroindustriais e econômicas. EDUFCG, Campina Grande, Brazil. p. 31-56.

Sutar, P.P., Nimkar, P.M., Gawande, S.B., Dhande, R.A. 2013. Physical properties of delinted cotton seeds. Journal of Food Research and Technology 1: 29-35.

Toledo, F.F., Barbin, D. 1968. Estudossobresementes de algodoeiro deslintadas mecanicamente, à flama e quimicamente. In: Seminário Brasileiro de Sementes, 1, Viçosa. Anais... Viçosa, Imprensa Universitária da Universidade Rural. 